\title{
TURIZM IŞLETMELERINE
}

SAĞLANAN DEVLET TEŞVIKLERININ

MUHASEBELEŞTIRILMESININ TMS-20

STANDARDI VE TEKDÜZEN MUHASEBE

SISTEMI AÇISINDAN KARŞILAŞTIRILMASI*

Arş.Gör. Gülçin KARATAŞa

Prof.Dr. Nilüfer TETiK ${ }^{b}$

Örnek Olay (Vak’a) Tahlili

(Case Analysis)

Muhasebe ve Vergi

Uygulamaları Dergisi

Mart 2018; 11 (1): 1-26

öz

Yatırım ağırlıklı bir sektör olan turizm sektörü, Türkiye'de özellikle 1980 yılından sonra sağlanan devlet teşviklerinin etkisi ile önemli bir gelişme göstermiş ve ülkenin ekonomik zorluklar yaşadığı dönemlerde sağladığı döviz girdisi ile dış açı̆̆ın ve işsizliğin azaltıımasında, ödemeler dengesinin iyileştirilmesinde önemli bir paya sahip olmuştur.

Çalışmada teşvik kavramı ve Türkiye'de turizm sektörüne yönelik olarak sağlanan devlet teşvikleri, TMS-20 standardı ve Tekdüzen Muhasebe Sistemi detaylı bir şekilde açıklanmıştı. Devlet teşviklerinin muhasebeleştirilmesi TMS-20 Standardı ve Tekdüzen Muhasebe Sistemi açısından karşılaştırmalı olarak incelenerek benzerlikler ve farklııklar tespit edilmeye çalışılmış ve bu kapsamda varsayımsal bir örnek uygulamaya yer verilmiştir. Turizm işletmelerine sağlanan teşvik türlerinden başıcalarını içeren örnek uygulamada devlet teşvikleri, hem TMS 20'ye göre hem de Tekdüzen Muhasebe Sistemi'ne göre muhasebeleştirilmiştir. Sonuç kısmında uygulamalar karşılaştırılarak farklılıkların giderilmesi amaçlanmış ve önerilerde bulunulmuştur.

Anahtar Sözcükler: TMS-20 Standardı, Tekdüzen Muhasebe Sistemi, Devlet Teşvikleri.

JEL Kodları: M41, M48, M49

* Makalenin gönderim tarihi: 25.01.2017; Kabul tarihi: 16.09.2017 ve iThenticate benzerlik oranı \% 12

a Akdeniz Üniversitesi, Sosyal Bilimler Enstitüsü, Turizm Işletmeciliği ABD, Öğretim Elemanı, E-posta: gulcinkaratas@akdeniz.edu.tr, ORCID: http:// orcid.org/0000-0002-6060-8726 (Sorumlu yazar; Correspondent author)

b Akdeniz Üniversitesi Turizm Fakültesi Turizm Işsletmeciliği Bölümü, Turizm Işsletmeciliği ABD Öğretim Üyesi, E-posta: niltetik@akdeniz.edu.tr, ORCID: http:// orcid.org/0000-0001-6434-8039 
COMPARISON OF ACCOUNTING FOR GOVERMENT GRANTS PROVIDED TO TOURISM COMPANIES IN TERMS OF TAS-20 STANDARD AND UNIFORM ACCOUNTING SYSTEM

\section{ABSTRACT}

Tourism, which is an investment oriented sector, particularly after 1980s developed significantly in Turkey, with the support of government grants for the sector and it has an important role in the improvement of balance of payments, decrease in balance of payments deficit and unemployment rates via foreign exchange inflow to the country in financially distressed periods.

The concept of grant and the government grants provided to the tourism sector in Turkey, TAS-20 Standard and the Uniform Accounting System are explained in detail within this study. It is attempted to identify similarities and differences by examining comparatively the accounting for government grants in terms of TAS-20 Standard and Uniform Accounting System, and in this context a hypothetical application is included. In the hypothetical application which includes the main types of grants provided to tourism enterprises, accounting for the government grants is applied in accordance with both TAS-20 and Uniform Accounting System. In the conclusion section, it is aimed to eliminate the differences by comparing the applications and then suggestions are presented.

Keywords: TAS-20, Uniform Accounting System, Government Grants.

JEL Codes: M41, M48, M49

\section{GiRiş ${ }^{1}$}

Teşvikler, yatırımların maliyetlerinin düşürülmesi, yatırımların gerçekleşmesi için gereken finansmanın sağlanması, işletmelerin vergi yükünün hafifletilmesi ve ihtiyaç duyulan bölgelere yatırım yapılmasının sağlanması açısından oldukça etkili araçlardır. Devlet bu araçları kullanırken bölgesel farklılıkların ortadan kaldırılması, uluslararası alanlarda rekabet gücünün artırılması ve yabancı yatırımcıların ülke ekonomisine çekilmesi gibi amaçları da benimsemektedir.

Türkiye'de bu alanda etkili devlet teşvikleri, planlı dönemle birlikte başlamış; yatırım, işletme ve pazarlama aşamalarında yatırımcılara ve işletmelere sağlanmıştır. Özellikle 1980'den sonra işletmelere ve yatırımcılara

1 Bu çalıșma, yazarın Akdeniz Üniversitesi Sosyal Bilimler Enstitüsü Turizm Işsletmeciliği ve Otelcilik ABD'de Prof. Dr. G. Nilüfer TETiK danışmanlığında yürütülen "Turizm İşletmelerinde Devlet Teşviklerinin TMS-20 Standardı ve Yasal Düzenlemeler Açısından Incelenmesi" adlı yüksek tezinden yararlanılarak hazırlanmıştrr. 
sağlanan nakdi ve nakdi olmayan teşvikler sayesinde turizm gelirlerinde ciddi artışlar meydana gelmiştir.

Sağlanan teşvikler bir yandan ekonomiye önemli katkılar sağlarken bir yandan da devlete oldukça büyük bir maliyet yüklemektedir. Ancak sağlanan bu teşviklerin ülke ekonomisine olan etkisi uzun sürede kendisini göstermektedir. Maliyet ve bu maliyetin geri dönüşü konusunda yaşanan bu olumsuzluğa rağmen ülkeler teşvik sağlamaktan vazgeçmemekte, ekonomik gelişim uzun sürede gerçekleşecek olsa dahi teşvik sağlamaya devam etmektedir.

Küreselleşme nedeniyle artan sermaye hareketliliği uluslararası yatırımları da artırmıştır. Ancak ülkelerin muhasebe ve raporlama sistemlerinin birbirinden farklı olması yapılan yatırımlarla ilgili bazı riskleri de beraberinde getirmektedir. Bu risklerin en önemlisi muhasebe ve raporlama sistemlerinin birbirinden farklı olması nedeniyle finansal tabloların yeterince anlaşılamaması ve bunun sonucu olarak da yatırım kararlarının hatalı olması riskidir. Söz konusu riskleri ortadan kaldırabilmek amacıyla yapılan çalışmaların sonucunda Uluslararası Muhasebe Standartları ortaya çıkmıştır. Bu standartlar sayesinde uluslararası alanda ortak bir muhasebe ve raporlama sisteminin oluşması sağlanmıştır. Ancak ülkelerin vergi kanunları kapsamında yaptıkları farklı uygulamalar muhasebe ve raporlama sistemini etkilemektedir. Bu nedenle ulusal muhasebe standartları ile uluslararası muhasebe standartları arasındaki uygulama farklılıkları tam anlamıyla ortadan kaldırılamamaktadır.

Ülkemizde muhasebe uygulamaları genel olarak vergi mevzuatına göre ve vergi matrahının tespitine yönelik öncelikler dikkate alınarak yapılmaktadır. 1992 yılında Resmi Gazete'de yayınlanarak yürürlüğe giren 1 sıra no.lu Muhasebe Sistemi Uygulama Genel Tebliği'nde (MSUGT), işletmelerin muhasebe sistemlerini bu tebliğ ve ekinde öngörülen kurallara uygun olarak yürütecekleri belirtilmiş olup, vergiye tabi karın tespiti aşamasında vergi kanunlarında yer alan özel hükümlerin göz önünde bulundurmasının kanuni bir zorunluluk olduğu belirtilmiştir.

Bu çalışmada, turizm sektörüne sağlanan devlet teşviklerinin muhasebeleştirilmesi konusu, TMS-20 Standardı ve Tekdüzen Muhasebe Sistemi (TDMS) açısından karşılaştırmalı olarak ele alınarak, sağlanan teşvik türlerinden başlıcalarını içeren örnek bir uygulama ile uygulamalar arasındaki benzerliklerin ve farklılıkların ortaya çıkarılması amaçlanmış ve önerilerde bulunulmuştur. 


\section{TÜRKIYE'DE TURIZM SEKTÖRÜNE SAĞLANAN DEVLET TEŞVIKLERI}

Bu bölümde teşvik kavramı ve turizm sektörüne sağlanan devlet teşvikleri açıklanmıştır.

\subsection{Teşvik Kavramı}

Ülkenin mevcut ekonomik sistemine göre değişiklik göstermekle birlikte teşviklerin temel amacı halkın refah düzeyinin yükseltilmesidir (Yavuz, 2010: 86). Bir kolaylık ve motivasyon aracı olan teşvik uygulamaları; yatırımların maliyetlerini azaltmak, finansman ihtiyaçlarını düşürmek, karlılı̆ı arttırmak ve yatırımları belli alanlara kaydırmak gibi alt amaçlara hizmet etmektedir (Aydoğuş vd., 2006: 3).

Teşvik kavramı, kamunun bazı sektörlerin ya da belirli ekonomik faaliyetlerin gelişimini hızlandırabilmek için verdikleri maddi ve manevi destekler ile birlikte o sektörlere karşı bir özenti oluşturabilmek için yaptı̆̆ yardımlardır (Çiloğlu, 1997: 1). Teşvikler özellikle özel sektördeki girişimcilerin yatırım, ihracat ve benzeri iktisadi faaliyetlerde bulunma arzu ve isteklerin arttrılması için devletin kullandığı etkili bir araçlardır (Öner, 2002: 98).

Teşvik kavramının literatürde birçok tanımı yapılmıştır. Teşvik ve Uygulama Genel Müdürlüğü tarafindan benimsenen ve sıklıkla kullanılan tanıma göre teşvik; "belirli ekonomik faaliyetlerin diğerlerine oranla daha fazla ve hızlı gelişmesini sağlamak amacıyla kamu tarafindan çeşitli yöntemlerle verilen nakdi ve nakdi olmayan destek ve özendirmelerdir" şeklinde tanımlanmaktadır (Ulusan, 2008: 416).

20 no'lu Türkiye Muhasebe Standardı́nın 3. paragrafinda ise teşvikler, "işletmenin faaliyet konusuyla ilgili olarak belli şartların geçmişte ya da gelecekte yerine getirilmesiyle işletmeye sağlanan kaynak transferi şeklinde devlet yardımları" olarak tanımlanmaktadır (TMS 20 Hakkında Tebliğ, Sıra No: 8).

TMS-20 standardı ile Turizmi Teşvik Kanunu'nun "Teşvik (Devlet Teşviki)" kavramına bakış açısı farklılık göstermektedir. Standarda göre devlet teşviki, işletme veya işletme gruplarına nakdi ile nakdi olmayan varlıkların transfer edilmesi anlamını taşımaktadır. Standart açısından, bunların dışında kalan teşvikler, devlet yardımı niteliğinde sayılmaktadır.

Turizmi Teşvik Kanunu'na göre teşvikler ise işletme ya da işletme gruplarına nakdi ve nakdi olmayan varlıkların transfer edilmesi de dahil diğer bütün destekleri kapsamaktadır. Yani Standart açısından bir teşvikten söz edebilmek için kaynak transferinin gerçekleşmesi esastır. Fakat Turizm Teşvik Kanunu açısından bir teşvikten söz edebilmek için mutlaka kaynak transferinin olması şart değildir. Kaynak transferi oluşturmayan destekler de teşvik olarak adlandırılmaktadır. 


\subsection{Türkiye'de Turizm Sektörüne Sağlanan Devlet Teşvikleri}

Ülkemizde turizm sektörüne sağlanan teşvik (destek) unsurları çıkarılan yasalar çerçevesinde belirlenmektedir (Toker, 2007: 86). Ancak, ülkemizde teşvik sistemi son derece karmaşık bir yapıya sahiptir. Bunun nedenleri arasında; teşviklerle ilgili düzenlemelerin farklı mevzuat türleri ile yapılması, bazı teşviklerin süreyle sınırlandırılması ve düzenleme yapan kurumların farklılık göstermesi sayılabilir. Bu durum teşvik sisteminin uygulanması konusunda ciddi problemlerle karşılaşılmasına ve teşviklerden yeteri kadar faydalanılamamasına neden olmaktadır (Akay, 2009: 33). Genel olarak ülkemizde turizm sektörüne sağlanan teşvikler Tablo 1'de özet olarak gösterilmiştir.

Tablo-1: Türkiye'de Turizm Sektörüne Sağlanan Teşvikler

\begin{tabular}{|c|c|}
\hline Kanun & Sağladığı Kolaylıklar \\
\hline \multirow{7}{*}{$\begin{array}{l}2634 \text { sayılı "Turizmi Teşvik } \\
\text { Kanunu" }\end{array}$} & -Turizm Kredileri \\
\hline & -Orman Fonuna Katkının Taksitlendirilmesi \\
\hline & -Elektrik, Havagazı ve Su Ücretleri \\
\hline & -Haberleşme Kolaylıkları \\
\hline & -Personel Çalıştırılması \\
\hline & -Resmi tatil, Hafta sonu ve Öğle Tatilleri \\
\hline & -Kamu Taşınmazlarının Tahsisi \\
\hline \multirow{10}{*}{$\begin{array}{l}6401 \text { sayılı "ihracata Yönelik } \\
\text { Devlet Yardımlarına Iliş̧kin } \\
\text { Karar" ile } \\
13812 \text { sayılı "Ihracat, Ihracat } \\
\text { Sayılan Satış ve Teslimler Ile } \\
\text { Döviz Kazandırıcı Hizmet ve } \\
\text { Faaliyetlerde Vergi, Resim ve } \\
\text { Harç Istisnası Hakkında Karar" }\end{array}$} & -Ar-Ge Yardımı \\
\hline & -İstihdam Yardımı \\
\hline & -Pazar Araştırması ve Pazara Giriş Desteği \\
\hline & -Çevre Maliyetlerinin Desteklenmesi \\
\hline & $\begin{array}{l}\text {-Türk Ürünlerinin Yurtdışında Markalaşması, } \\
\text { Türk Malı İmajının Yerleştirilmesi ve }\end{array}$ \\
\hline & IURQUALIIY nIn DesteklenmesI \\
\hline & $\begin{array}{l}\text {-Uluslararası Nitelikteki Yurt İçi İhtisas } \\
\text { Fuarlarının Desteklenmesi }\end{array}$ \\
\hline & $\begin{array}{l}\text {-Yurtdışında Gerçekleştirilen Fuar } \\
\text { Katılımlarının Desteklenmesi }\end{array}$ \\
\hline & -Vergi, Resim ve Harç İstisnası \\
\hline & -ìhracatta KDV İstisnası \\
\hline \multirow{4}{*}{$\begin{array}{l}5084 \text { sayılı "Yatırımların } \\
\text { ve İstihdamın Teşviki ile } \\
\text { Bazı Kanunlarda Değişiklik } \\
\text { Yapılması Hakkında Kanun" }\end{array}$} & -Gelir Vergisi Stopajı Desteği (\%80 oranında) \\
\hline & $\begin{array}{l}\text {-Sigorta Primi İşveren Paylarının Ödenmesi } \\
\text { (\%80 oranında) }\end{array}$ \\
\hline & -Enerji Desteği \\
\hline & -Bedelsiz Yatırım Yeri Tahsisi \\
\hline
\end{tabular}




\begin{tabular}{|c|c|}
\hline $\begin{array}{l}5510 \text { sayılı "Sosyal Sigortalar } \\
\text { ve Genel Sağlık Sigortası } \\
\text { Kanunu" }\end{array}$ & 100 TL Sigorta Primi İşveren Payı İndirimi \\
\hline \multirow{2}{*}{$\begin{array}{l}\text { 2006/10921 sayılı } \\
\text { "Yatırımlarda Devlet } \\
\text { Yardımları Hakkında Karar" }\end{array}$} & -KDV İstisnası \\
\hline & -Faiz Desteği \\
\hline $\begin{array}{l}1319 \text { sayılı "Emlak Vergisi } \\
\text { Kanunu" }\end{array}$ & -5 yıl süre ile geçici muafiyet \\
\hline $\begin{array}{l}4875 \text { sayılı "Doğrudan Yabancı } \\
\text { Yatırımlar Kanunu" }\end{array}$ & $\begin{array}{l}\text {-Önceden şart koşulan izleme, onay, pay transferi ve } \\
\text { minimum sermaye gibi şartlardan muaf olarak } \\
\text { yatırım özgürlüğü sağlanması } \\
\text {-Şeffaf ve tutarlı bir doküman ile yabancı } \\
\text { yatırımcıların mevcut haklarının garanti altına } \\
\text { alınması } \\
\text {-Kazanılmış hakların korunması, büyüme ve gelişme } \\
\text { için yatırımcı dostu iklimin sürekliliğini sağlamak } \\
\text { adına gerekli politika değişiminin sağlanması }\end{array}$ \\
\hline 2010/9 sayılı tebliğ & -Yurtdışı Turizm Fuarlarına Katılım Desteği \\
\hline $\begin{array}{l}6111 \text { sayılı Kanunu ile } \\
\text { düzenlenen "istihdam Teşviki" }\end{array}$ & $\begin{array}{l}\text {-Kanun kapsamında yer alan şartları sağlayan } \\
\text { çalışanların sigorta primi işveren payının } \\
\text { tamamının İşsizlik Sigortası Fonu'ndan } \\
\text { karşılanması }\end{array}$ \\
\hline $\begin{array}{l}\text { 2012/4 sayılı "Döviz } \\
\text { Kazandırıcı Hizmet Ticaretinin } \\
\text { Desteklenmesi Hakkında } \\
\text { Tebliğ" }\end{array}$ & $\begin{array}{l}\text {-Pazara Giriş Desteği } \\
\text {-Yurtdışı Tanıtım Desteği } \\
\text {-Yurtdışı Birim Desteği } \\
\text {-Belgelendirme Desteği } \\
\text {-Ticaret Heyeti ve Alım Heyeti Desteği } \\
\text {-Danışmanlık Desteği }\end{array}$ \\
\hline
\end{tabular}

Kaynak: Aydoğuş vd., 2006: 14'ten uyarlanmıştır.

\section{TURiZM işLETMELERINE SAĞLANAN DEVLET TEŞVIKLERININ MUHA- SEBELEŞTIRILMESi}

Çalışmanın bu bölümünde TMS-20 Standardı ve Tekdüzen Muhasebe Sistemi ile ilgili ayrıntılı bilgilere yer verilmiştir. Aynı zamanda turizm işletmelerine sağlanan devlet teşviklerinin muhasebeleştirilmesi konusu TMS-20 Standardı ve Tekdüzen Muhasebe Sistemi açısından ele alınarak açıklanmıştır.

\subsection{TMS-20 Standardına Göre Devlet Teşviklerinin Muhasebeleştirilme-} si

TMS-20 standardının amacı devlet teşviklerinin muhasebe standartlarına göre muhasebeleştirilmesinin açıklanmasıdır. Standart, teşvik ve yardımlardan sağlanan yararın ne şekilde raporlanabileceğini göstermektedir. İş- 
letmenin performansına göre alternatif yöntemler sunmaktadır (Kayalı ve Terim, 2012: 35).

TMS-20 Devlet Teşviklerinin Muhasebeleştirilmesi ve Devlet Yardımlarının Açıklanması standardında muhasebeleştirme esasları anlatılırken sık sık karşımıza çıkan kavramlar devlet teşvikleri ile devlet yardımları kavramıdır.

Devlet teşvikleri, devlet aracılığıyla işletmelere ya da diğer çeşitli iştiraklere kaynak aktarımı şeklinde sağlanan yardımlardır. Devlet tarafindan sağlanan feragat edilebilir krediler, işletmenin gerekli şartları yerine getirebileceğine dair makul bir güvencenin oluşması durumunda teşvik olarak kabul edilmektedir (Mackenzie vd., 2012: 551).

Devlet teşviklerini teşvike konu olan varlığa ya da sağlanan teşvik türüne göre sınıflandırmak mümkündür. Teşvike konu olan varlığa göre yapılan sınıflandırmada teşvikler, "Parasal teşvikler" ile "Parasal olmayan teşvikler" şeklinde iki ayrı grupta incelenmektedir. Parasal teşvikler, işletmeye doğrudan nakit ya da nakit benzeri varlıkların transfer edilmesi veya devlete olan birtakım yükümlülüklerin azaltılması şeklinde gerçekleştirilmektedir (TMS 20 Hakkında Tebliğ, Sıra No:8, Paragraf 3). Parasal olmayan teşvikler ise işletmenin kullanımına verilen arsa ya da diğer kaynaklardır (TMS 20 Hakkında Tebliğ, Sıra No:8, Paragraf 23).

Devlet yardımları ise destekleme, sübvansiyon ve teşvik kavramlarının tamamını kapsayan geniş bir tanıma sahiptir. Devlet yardımından yaralanan bir işletme bu yardım sayesinde rakiplere üstünlük sağlama veya mali yapısının güçlenmesi gibi doğrudan faydalar sağlamaktadır. Ancak dolaylı faydalar mevcut standardın kapsamı içinde yer almamaktadır (Gençoğlu vd., 2013: 589).

Devlet teşviklerinin muhasebeleştirilmesi hususu iki tür yaklaşımla ele alınmaktadır. Bunların ilki; teşvikin kar veya zarar dışında muhasebeleştirildiği, yani edinilen teşvikin bilançoda izlendiği sermaye yaklaşımıdır. İkincisi ise; teşvikin bir ya da daha fazla dönemde kar veya zararda muhasebeleştirildiği, yani edinilen teşvikin gelir tablosunda izlendiği gelir yaklaşımıdır (TMS 20 Hakkında Tebliğ, Sıra No:8, Paragraf 13-15).

Teşvikler sermaye yaklaşımı kapsamında muhasebeleştirildiği zaman kar veya zarar dışında muhasebeleştirilmeleri gerektiğinden bu amaca yönelik olarak "549 ÖZEL FONLAR" hesabı kullanılabilir (Akay ve Oğuz, 2015: 226).

Gelir yaklaşımı kapsamında muhasebeleştirildiğinde ise teşvikler hissedarlar dışındaki bir kaynaktan elde edildiğinden, direkt öz kaynak olarak kaydedilmemeli ancak uygun dönemlerde kar veya zarar olarak muhasebeleştirilmelidir (TMS 20 Hakkında Tebliğ, Sıra No:8, Paragraf 15). Bu amaca yönelik olarak gelir yaklaşımı kapsamında devlet teşvikleri "649 DiĞER 
OLAĞAN GELIR VE KARLAR" hesabı kullanılarak muhasebeleştirilebilir (Akdoğan ve Sevilengül, 2003: 25). Ancak tam açıklama ve kamuyu aydınlatma ilkesi dikkate alındığında teşviklerden elde edilen gelirlerin grup toplamını \%10'unu geçmesi durumunda 64 hesap grubunda Devlet Teşvik Gelirleri adıyla açılacak yeni bir hesapta takip edilmesi gerekli görülmüştür. Ancak tekdüzen hesap planında 64 hesap grubunda açılabilecek boş hesap kodu olmadığından teşviklerin "649 DiĞER OLAĞAN GELIR VE KARLAR" hesabının altında Devlet Teşvik Gelirleri adıyla izlenmesi uygun olacaktır. Ayrıca teşvik gelirlerinin saţşlarla ilgili olanlarının "602 DiĞER GELIRLER" hesabı, diğerlerinin ise teşvik gelirlerinin süreklilik arz edip etmemesine göre "649 DIĞER OLAĞAN GELIR VE KARLAR" hesabı veya "679 DiĞER OLAĞAN DIŞI GELIR VE KARLAR" hesabı kullanılarak muhasebeleştirilmesinin ve raporlanmasının, raporlama açısından daha doğru bir uygulama olacağı öngörülmüştür.

Turizm işletmeleri bir hizmet işletmesi olduğu için tekdüzen hesap planında ilgili maliyetler "740 HIZMET ÜRETIM MALIYETi" hesabında izlenmektedir. Ancak özellikle bir turizm işletmesi olan konaklama işletmelerinde malzeme maliyetleri ve işçilik giderleri hizmet üretim maliyeti içinde önemli bir paya sahiptir. Bu nedenle üretim işletmelerinde olduğu gibi turizm işletmelerinde de direkt ilk madde ve malzeme, direkt iş̧ilik ve dolaylı giderleri kapsayan giderlerin ayrı hesaplarda izlenmesi uygun olacaktr. Bu uygulamada tarafimızdan dolaylı giderler için "746 GENEL ÜRETIM GIDERLERi HIZMET MALIYETi", direkt işçilik giderleri için "744 DiREKT iş̧̧iLiK HIZMET GIDERLERi” adıyla iki yeni hesap açılmıştr. Böylece tam açıklama ve kamuyu aydınlatma ilkesi gereği muhasebeden bilgi talep edenlere daha ayrınthlı ve gerçeğe uygun bilgi sağlama olanağı doğmaktadır.

\subsection{Tekdüzen Muhasebe Sistemi'ne Göre Devlet Teşviklerinin Muhase- beleştirilmesi}

Tekdüzen Muhasebe Sisteminde (TDMS), devlet teşviklerinin muhasebeleştirilmesi ve finansal tablolarda raporlanması konusuna ilişkin olarak uyulması gereken usul ve esaslar 1 sıra no'lu tebliğde düzenlenmiştir. Tebliğde yapılan açıklamada "Muhasebe Usul ve Esasları" bölümünün, "V-Tekdüzen Hesap çerçevesi, Hesap Planı ve Hesap Planı açıklamaları" kısmında, devlet teşviklerinin muhasebeleştirilmesi ve raporlanması konusunda "602 DiĞER GELIRLER" hesabının kullanılması gerektiği belirtilmiş olup gerek bu tebliğde gerekse bu tebliği takip eden diğer 13 tebliğde muhasebeleştirme ve raporlama konusunda başka bir açıklamaya yer verilmemiştir.

Diğer Gelirler Hesabı, gelir tablosunda brüt satışlar hesap grubu içerisinde yer almaktadır. Ancak teşviklerin tamamı işletmelerin saţ̧ faaliyeti so- 
nucunda elde etmiş olduğu bir satş hasılat değildir. Bu şekilde yapılacak bir raporlama işletmenin brüt satışlarını arttrarak brüt satış karlılığının yüksek çıkmasına neden olacaktır. Bu nedenle teşvik gelirlerinin satışlarla ilgili olanlarının "602 DiĞER GELIRLER" hesabı, diğerlerinin ise teşvik gelirlerinin süreklilik arz edip etmemesine göre "649 DiĞER OLAĞAN GELIR VE KARLAR" hesabı veya "679 DIĞER OLAĞAN DIŞI GELIR VE KARLAR" hesabı kullanılarak muhasebeleştirilmesi ve raporlanması, raporlama açısından daha doğru bir uygulama olacaktır. Ancak Tekdüzen Muhasebe Sistemi'nde tam açıklama ve kamuyu aydınlatma ilkesi dikkate alındığında süreklilik arz etmeyen teşviklerden elde edilen gelirlerin grup toplamının \%10'unu geçmesi durumunda yeni açılacak bir hesapta izlenmesi öngörülmüştür.

\section{TURIZM IŞLETMELERINE SAĞLANAN DEVLET TEŞVIKLERININ MUHA- SEBELEŞTíRILMESINE iLIŞKiN UYGULAMA ÖRNEĞi}

Bu bölümde varsayımsal bir örnek uygulama yapılmış, daha sonra uygulama sonuçları ile ilgili değerlendirmelere yer verilmiştir. Uygulama aşamasında turizm işletmelerine sağlanan teşviklerin tamamı muhasebeleştirilmemiş, yalnızca belli başlı teşvikler muhasebeleştirilerek değerlendirmeye alınmıştır. Çünkü TMS-20 Standardına göre bir devlet teşvikinden söz edebilmek için kaynak transferinin gerçekleşmesi esastır. Turizmi Teşvik Kanunu'nda yer alan bu teşvikler, Standart kapsamında teşvik olarak nitelendirilmediğinden ve dolayısıyla işletmeye bir kaynak transferi içermediğinden sermaye yaklaşımına ve gelir yaklaşımına göre muhasebeleştirilmeleri söz konusu değildir. Bu nedenle Turizmi Teşvik Kanunu kapsamında sağlanan "Orman Fonuna Katkının Taksitlendirilmesi, Elektrik, Havagazı ve Su Ücretleri, Haberleşme Kolaylıkları, Personel Çalıştırılması, Alkollü içki Satışı, Resmi Tatil, Hafta Sonu ve Öğle Tatilleri" gibi teşvikler muhasebeleştirilememiştir.

Yine Turizmi Teşvik Kanunu kapsamında yer alan "Kamu Taşınmazlarının Turizm Yatırımcıları Için Yatırımcılara Tahsisi" teşviki de yukarıda belirtilen nedenden dolayı muhasebeleştirilememiştir. Ancak devlet tarafindan sağlanan bu teşvik önemli ölçüde olabileceğinden finansal tabloların dipnotlarında türünün, kapsamının ve süresinin açıklanması gerekmektedir (Akay ve Oğuz, 2015: 227).

Ihracata Yönelik Devlet Yardımları yoluyla yapılan "ihracat, Ihracat Sayılan Satış ve Teslimler ile Döviz Kazandırıcı Hizmet ve Faaliyetlerde Vergi, Resim ve Harç Istisnası Hakkında Karar"a göre sağlanan turizm teşvikleri ile Devlet Yardımlarıyla Sağlanan Turizm Teşvikleri kapsamında yer alan "Katma Değer Vergisi İstisnası" muhasebeleştirilememiştir. Çünkü işletmelere vergilendirilebilir kar ya da vergi zararının hesaplanmasında yararlanmak 
üzere sağlanan faydalar ile vergi yükümlülüğüne bağlı olarak belirlenen ya da vergi yükümlülüğü ile sınırlı olarak sağlanan devlet yardımları standardın kapsamı dışındadır (TMS 20 Hakkında Tebliğ, Sıra No:8, Paragraf 2 (b) Bendi). Bu nedenle bu teşvikin TMS-20 standardına göre muhasebeleştirilmesi söz konusu değildir.

Yukarıda bahsedilen tüm bu teşvikler TMS-20 standardına göre muhasebeleştirilemediği için sağlıkı bir karşılaştırmanın yapılabilmesi adına Tekdüzen Muhasebe Sistemi açısından da muhasebeleştirilmemiştir.

\subsection{Uygulama Örneğine İlişkin Açıklamalar}

Uygulama örneğine ilişkin bilgiler aşağıdaki gibidir;

A Turizm A.Ş. 01.11.2006 yılında Şanlıurfa'da (VI. Bölge), 2634 Sayılı Turizmi Teşvik Kanunu kapsamında 49 yıllı̆ına tahsis edilen arazi üzerine kurulmuş, sağlık turizmi kapsamında Sağlık Bakanlığı tarafindan ruhsatlandırılmış 80 yataklı bir termal konaklama tesisi yer alan ve turizm sektöründe faaliyet gösteren bir işletmedir. Aynı zamanda yatııı teşvik belgesine sahiptir.

A Turizm A.Ş. bünyesinde bulunan konaklama tesisinde toplam 30 çalışan bulunmaktadır. Personellerin tümü bekar ve 16 yaşın üzerindedir.

Tablo-2: Konaklama Tesisi Personel Bilgileri (30 Çalışan)

\begin{tabular}{|l|c|c|c|}
\hline \multicolumn{1}{|c|}{ Bölüm } & Statü & Çalışan Sayısı & Aylık Brüt Ücret \\
\hline Genel Yönetim Bölümü & Yönetici & 5 & $4.196,33 \mathrm{TL}$ \\
\hline Pazarlama Bölümü & Yönetici & 1 & $4.196,33 \mathrm{TL}$ \\
\hline & İşçi & 24 & $* 1.647 \mathrm{TL}$ \\
\hline
\end{tabular}

*2016 yılı brüt asgari ücret tutarıdır. (2017 yılı brüt asgari ücret tutarı 1.777,50 TL olmuştur.)

Türk Ticaret Kanunu'nun üçüncü bölümünde yer alan 43. Madde kapsamında A Turizm A.Ş. unvanı ile ticari faaliyetine başlayan işletmenin 2016 yılı içerisinde gerçekleştirdiği faaliyetler aşağıda yer almaktadır. (Hesaplamalarda 2016 yılı ortalama dolar kuru esas alınmıştr.1 $\$=3,03$ TL olarak dikkate alınacaktr.)

a) İşletmenin Ağustos ayına ait elektrik faturası \%18 KDV dahil 8.260 TL'dir. İşletme ödediği faturayla ilgili belgelerle Hazine'ye başvurmuş ve 5084 sayılı kanun kapsamında \%20 oranında enerji desteğinden yararlanması uygun bulunmuştur.

b) A Turizm A.Ş. elde ettiği teşvik belgesi sayesinde 5084 sayılı kanun uyarınca brüt asgari ücret üzerinden hesaplanan sigorta primi işveren payının 
c) \%80'i Hazine tarafindan karşılanmaktadır. Ayrıca 5510 sayılı kanun kapsamında asgari ücretle çalışan her bir işçi için 100 TL sigorta primlerinden mahsup edilmektedir. Çalışanlara ilişkin ücret ve SGK işveren payı desteğine ilişkin detaylar tablo 3'teki gibidir.

Tablo-3: Konaklama Tesisi Bünyesinde Çalışan Personeller İçin Sağlanan SGK İşveren Payı Desteğine İlişkin Detaylar

\begin{tabular}{|c|c|c|c|c|c|c|c|c|c|c|c|}
\hline 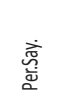 & 夢: & 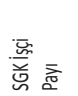 & 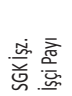 & 訔 & 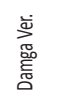 & 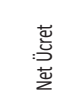 & 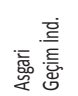 & 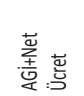 & 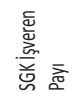 & 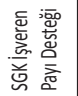 & 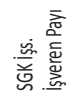 \\
\hline 5 & $20.981,65$ & $2.937,45$ & 209,80 & $2.675,15$ & 159,25 & $15.000,00$ & 617,65 & $15.617,65$ & $3.252,15$ & $1.021,12$ & 419,65 \\
\hline 1 & $4.196,33$ & 587,49 & 41,96 & 535,03 & 31,85 & $3.000,00$ & 123,53 & $3.123,53$ & 650,43 & 204,22 & 83,93 \\
\hline 24 & $39.528,00$ & $5.533,92$ & 395,28 & $5.039,76$ & 300,00 & $28.259,04$ & $2.964,72$ & $31.223,76$ & $6.126,72$ & $4.901,38$ & 790,56 \\
\hline Top. 30 & $64.705,98$ & $9.058,86$ & 647,04 & $8.249,94$ & 491,10 & $46.259,04$ & $3.705,90$ & $49.964,94$ & $10.029,30$ & $6.126,72$ & $1.294,14$ \\
\hline
\end{tabular}

d) İşletme sağlık turizmi kapsamında sunduğu hizmeti tanıtmak için Google arama motoruna arama ağı reklamı vermiştir. Reklam için Google'a 4.000 \$ ödeme yaptıktan ilgili belgeleri Ekonomi Bakanlığına ibraz etmiş ve 2012/4 sayılı tebliğ kapsamında tanıtım desteğinden yararlanmaya hak kazanmıştır (Okutmuş, Uyar ve Gövce, 2015; 74). (Teşvik tutarı yapılan harcamaların \%50'si kadardır.)

e) İşletmenin 2016 yılı net satış hasılat 1.570.000 TL'dir. Bunun 1.150.000 TL'lik kısmını yurtiçi satışlar, 420.000 TL'lik kısmını ise yurtdışı satışlar oluşturmaktadır.

f) 2016 yılı satilan hizmet maliyeti 520.000 TL'dir.

g) İşletme, konaklama tesisini büyütmek için aldığı kısa vadeli banka kredisi için 30.000 TL faiz ödemiştir.

h) İşletmenin 2016 yılı Pazarlama, Satış, Dağıtım Giderleri 180.000 TL'dir.

i) İşletmenin 2016 yılı Genel Yönetim Giderleri 290.000 TL'dir.

j) İşletme, 2016 yılı içerisinde vadeli mevduat hesabından 20.000 TL faiz geliri elde etmiştir.

k) 2016 yılı içinde işletmenin 12.000 TL kur farkı gideri oluşmuştur.

I) İşletmenin döviz hesabında bulunan tutar değerleme sonucunda 27.000 TL kur farkı geliri oluşmuştur.

\subsection{Uygulama Örneğinde Yer Alan İşletmeye Sağlanan Devlet Teşvikle- rinin Muhasebeleştirilmesi}

Yukarıdaki örnekte verilen bilgiler doğrultusunda, A Turizm A.Ş.'nin 2016 yılında yaptığı işlemler ve yararlanmış olduğu teşviklere ilişkin muhasebe kayıtları ilk olarak TMS-20 Devlet Teşviklerinin Muhasebeleştirilmesi ve Devlet Yardımlarının Açıklanması Standardı kapsamında iki ayrı yaklaşıma 
göre muhasebeleştirilecek daha sonra ise Tekdüzen Muhasebe Sistemi'nde yer alan usul ve esaslara göre muhasebeleştirilecektir. Son olarak da sonuçlar karşılaştırılacak ve aradaki farklara değinilecektir.

\subsubsection{TMS-20 Standardına Göre Muhasebeleştirilme}

TMS-20 Standardı kapsamında muhasebeleştirme işlemleri sermaye yaklaşımı ve gelir yaklaşımı şeklinde iki tür yaklaşımla ele alınmaktadır. A Turizm A.Ş.'nin yararlandığı teşvik türleri sırasıyla sermaye yaklaşımı ve gelir yaklaşımına göre aşağıda muhasebeleştirilecektir.

\subsubsection{Sermaye Yaklaşımına Göre Muhasebeleştirme}

Sermaye yaklaşımı doğrultusunda yapılan çözümler aşağıda sırasıyla yer almaktadır.

\section{a) Enerji Desteği}

Faturanın tahakkuk kaydı aşağıdaki gibidir.

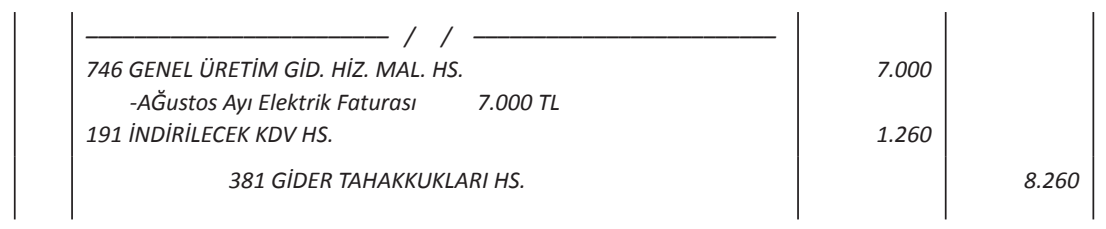

Fatura ödendiğinde yapılması gereken muhasebe kaydı aşağıdaki gibidir.

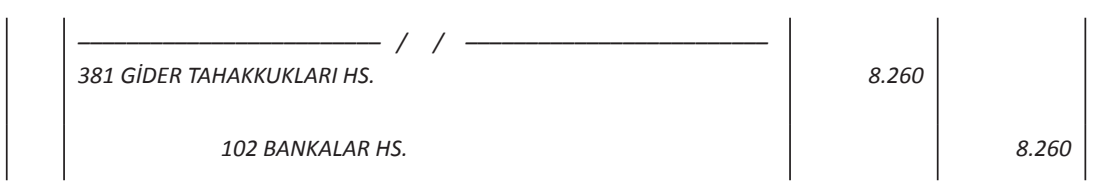

İşletmenin teşvik almaya hak kazandığı bildirildiğinde yapılması gereken muhasebe kaydı aşağıdaki gibidir. (Teşvik tutarı ilgili giderin \%20'si kadardir.) $(7.000 T L \times 0,20=1.400 T L)$

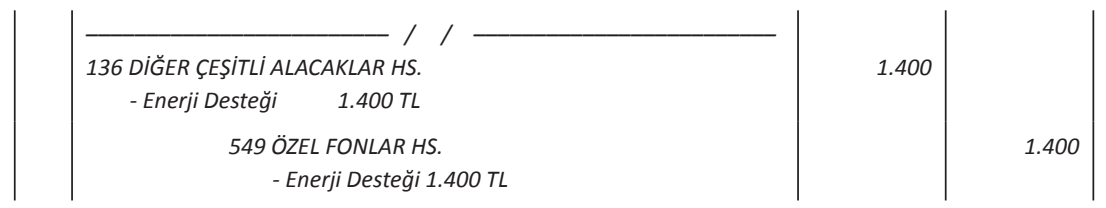

TMS-20 standardında bu tarz elde edilen teşviklerin sermaye yaklaşımına göre kayıt edildiğinde gelir tablosu hesaplarına ne zaman aktarılacağı belirtilmemiştir. Fakat dönem sonunda tarafimızdan açılan "746 GENEL ÜRETIM GIDERLERI HIZMET MALIYETi" hesabı dolaylı olarak gelir tablosu hesaplarında gider olarak gözükecektir. İşletmenin yapmadığı bir gider, gelir tablosu hesabında yer alacak ve işletmenin karını olduğundan daha az gösterecektir. Bu uygulama ile işletmenin dönem karının düşük ancak öz kaynaklarının yüksek görünmesine neden olacaktır. 


\section{b) Sigorta Primi İşveren Payı Teşviki}

Ücret tahakkuk kaydı aşağıdaki gibi olacaktır.

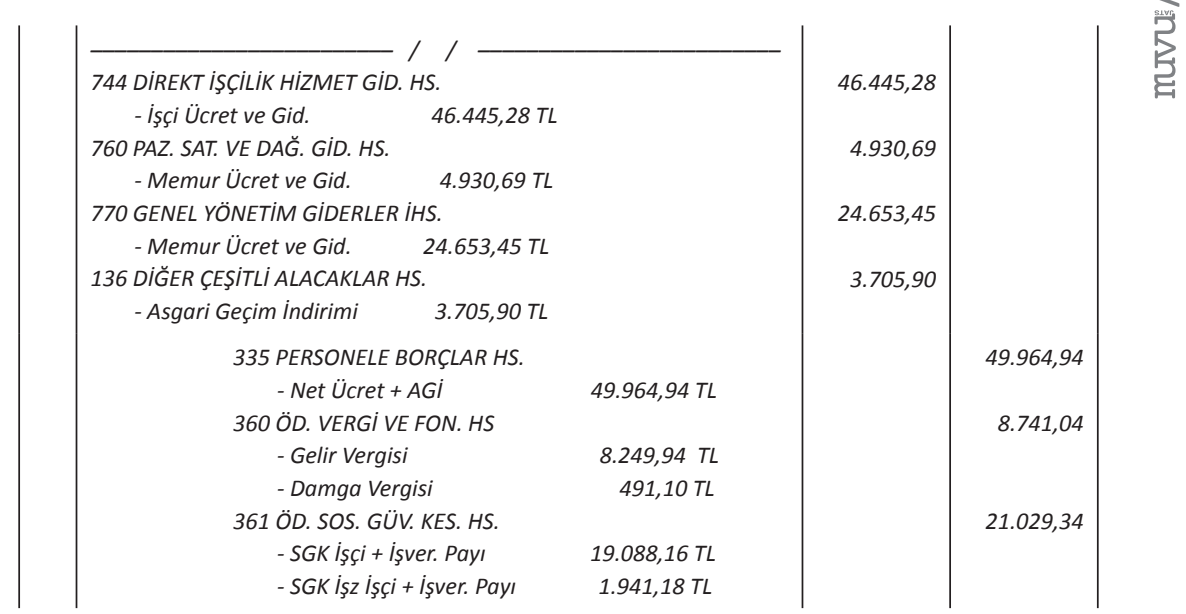

İşletme teşvikten yararlandığında yapılacak kayıt aşağıdaki gibidir.

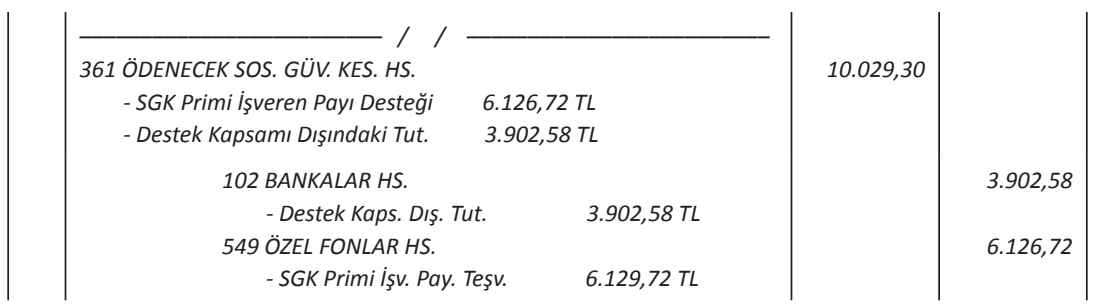

İşletmede çalışan personeller asgari ücretin üzerinde bir ücret alsalar bile yararlanabilecekleri sigorta primi işveren payı teşvik tutarı, brüt asgari ücret üzerinden hesaplanan tutarın yüzde sekseni kadardır.

Ayrıca 2016 yılı Ocak ayında asgari ücretlerin 1.300 TL'ye yükseltilmesi nedeniyle işverenlerin maliyetlerinin artması yeni bir teşviki de beraberinde getirmiştir. Bu kapsamda asgari ücretle çalışan 24 iş̧̧inin her biri için 100 TL sigorta primi işveren payı indirimi sağlanmıştır.

Bu teşvik için yapılacak muhasebe kaydı aşağıdaki gibidir.

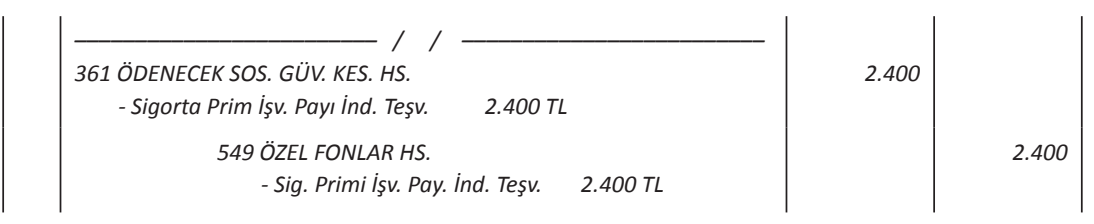

\section{c) Yurtdışı Tanıtım Desteği}

Verilen reklam ile ilgili olarak yapılmış olan harcamalar aşağıdaki gibi muhasebeleştirilmelidir. (4.000 $\$$ × 3,03 TL = $12.120 \mathrm{TL}$ ) 
Teşvik kapsamında geri alınacak tutarın tahakkukuna ilişkin muhasebe kaydı aşağıdaki gibi olacaktır. (Teşvik tutarı ilgili harcamaların \%50'si kadardır.) (2.000\$ $\times 3,03 T L=6.060 T L)$

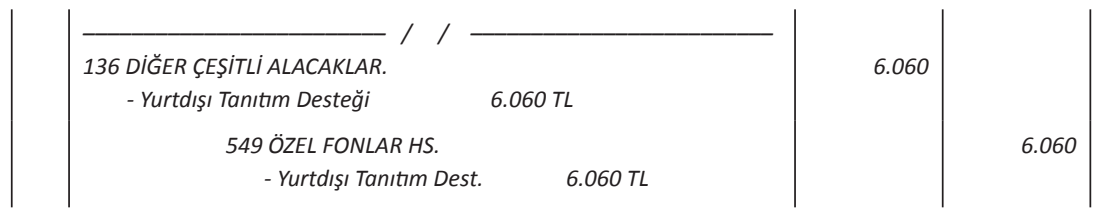

Sermaye yaklaşımına göre elde edilen teşvikler bilançoda öz kaynaklar kalemi altında "549 ÖZEL FONLAR" hesabı ile ilişkilendirildiği için elde edilen teşvik ve desteklerin kara bir etkisi olmamaktadır. Bu nedenle işletmenin dönem karı düşük ancak öz kaynakları yüksek görünmektedir Bu yöntem, bu yönüyle teşvik ve desteklerin özüne aykırı olmayacak şekilde raporlanmasını sağlamaktadır. Ancak alınan teşviklerin bilançoda ya da dipnotlarında açıklanması sosyal sorumluluk ve tam açıklama kavramları ile kamuyu aydınlatma ilkesi açısından önemli olacaktır.

\subsubsection{Gelir Yaklaşımına Göre Muhasebeleştirme}

Gelir yaklaşımı doğrultusunda yapılan çözümler aşağıda yer almaktadır.

\section{a) Enerji Desteği}

Faturanın tahakkuk kaydı aşağıdaki gibidir.

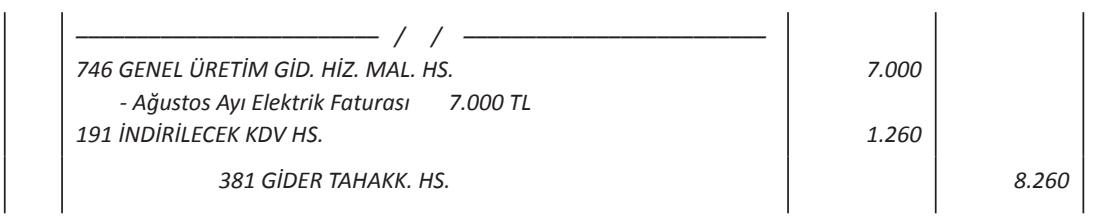

Fatura ödendiğinde yapılması gereken muhasebe kaydı aşağıdaki gibidir.

381 GIDER TAHAKKUKLARI HS.

102 BANKALAR HS. 
İşletmenin teşvik almaya hak kazandığı bildirildiğinde yapılması gereken muhasebe kaydı aşağıdaki gibidir.

\section{(7.000 TL $\times 0,20=1.400 T L)$}

136 DIĞER ÇEŞiTLI ALACAKLAR HS.

- Enerji Desteği 1.400 TL

602 DIĞER GELIRLER HS.

- Enerji Desteği 1.400 TL

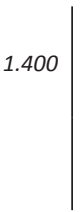

Bu teşvik gelir yaklaşımına göre muhasebeleştirildiğinde; elde edilen teşvik geliri, gelir tablosu hesabında izlendiği için dönem sonunda hesaplanan kar veya zarar doğru tutarı yansıtacaktır (Küçükkahraman, 2013: 88).

\section{b) Sigorta Primi İşveren Payı Teşviki}

Ücret tahakkuk kaydı aşağıdaki gibi olacaktır.

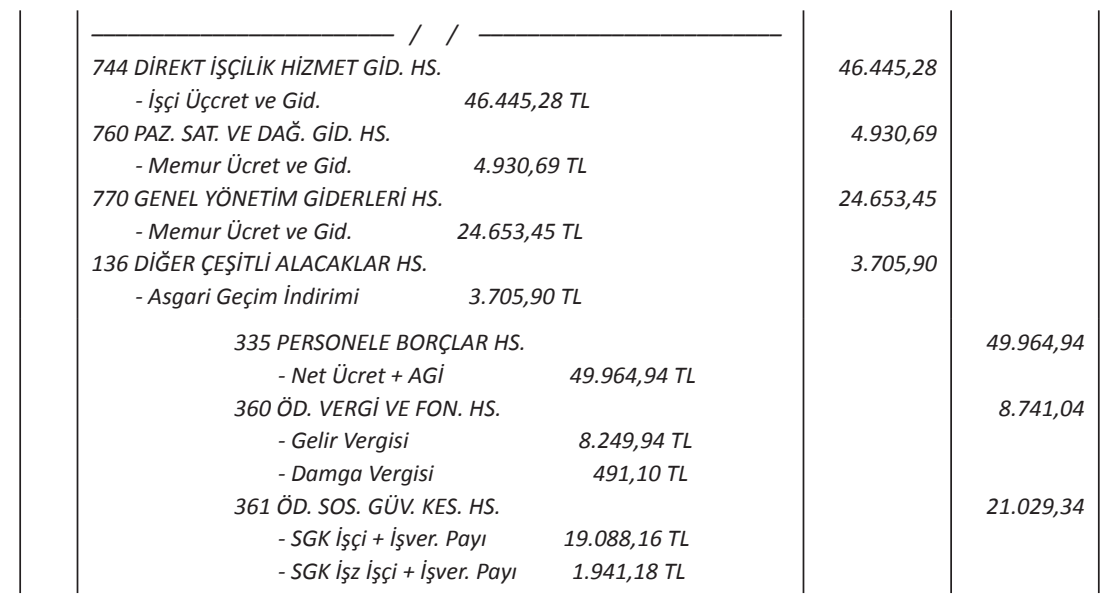

İşletme teşvikten yararlandığında yapılacak kayıt aşağıdaki gibidir.

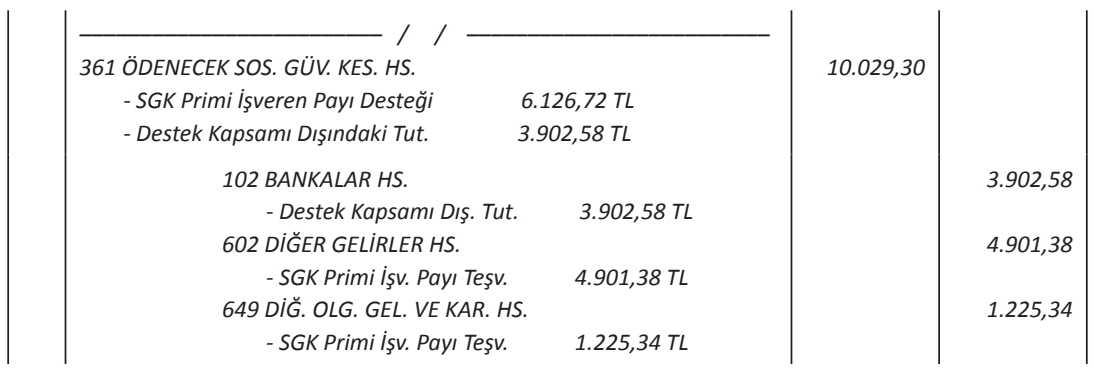

İşçi statüsünde, asgari ücretle çalışan personellere ilişkin sigorta primi işveren payı teşvikleri hizmet üretim maliyeti ile ilgili olduğundan ve gelir tablosunun brüt satı̧ karı bölümünde yer alması gerektiğinden "602 DiĞER GELIRLER" hesabında muhasebeleştirilmiştir. Pazarlama departmanı ile Genel Yönetim departmanında çalışan personeller için sağlanan sigorta 
primi işveren payı teşvikleri ise toplamları alınarak "649 DiĞER OLAĞAN GELIR ve KARLAR" hesabında muhasebeleştirilmiştir.

Yeni çıkarılan teşvik kapsamında asgari ücretle çalışan 24 iş̧̧inin her biri için 100 TL sigorta primi işveren payı indirimi sağlanmaktadır. Bu teşvik için yapılacak muhasebe kaydı aşağıdaki gibidir.

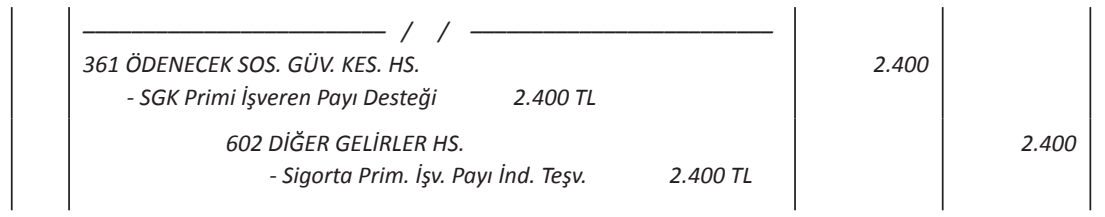

\section{c) Yurtdışı Tanıtım Desteği}

Reklam giderleri aşağıdaki gibi muhasebeleştirilmelidir. (4.000\$ x 3,03 TL $=12.120 \mathrm{TL}$ )
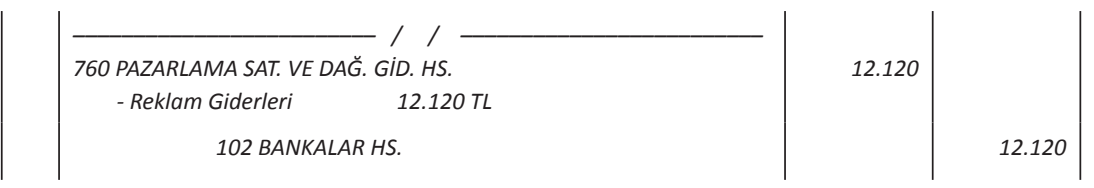

Teşvik kapsamında geri alınacak tutarın tahakkukuna ilişkin muhasebe kaydı aşağıdaki gibi olacaktır. (2.000 $\$$ × 3,03 TL = 6.060 TL)

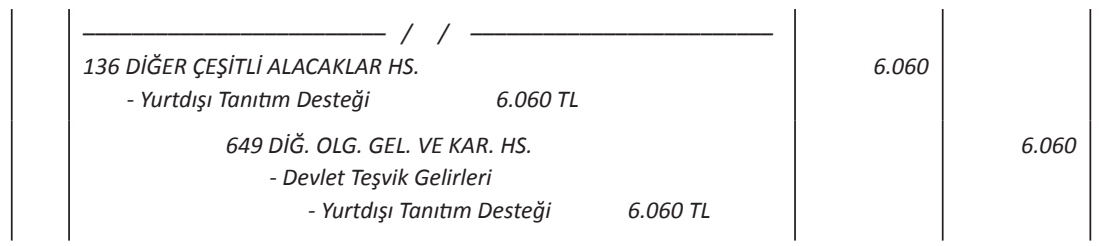

Gelir yaklaşımında varlıklara ilişkin teşvik bedelleri sistematik ve oransal bir biçimde gelir tablosuna aktarıldığı için kara etkisi daha az olmaktadır. Varlık dışı edinilen teşvikler ise bu yöntemde doğrudan gelir olarak kaydedilmektedir. Bu yönüyle gelir yaklaşımı teşviklerin özüne tam olarak uymasa da finansal tabloların daha gerçekçi bir yaklaşımla raporlanmasına hizmet etmektedir.

\subsubsection{Tekdüzen Muhasebe Sistemine Göre Muhasebeleştirilmesi}

Devlet teşviklerinin Tekdüzen Muhasebe Sistemi (TDMS) açısından muhasebeleştirme ve raporlama işlemleri 1 sıra no'lu tebliğde belirtilen usul ve esaslara göre yapılmaktadır. Bu kapsamda yapılan çözümler sırasıyla aşağıda yer almaktadır;

\section{a) Enerji Desteği}

Faturanın tahakkuk kaydı aşağıdaki gibidir. 


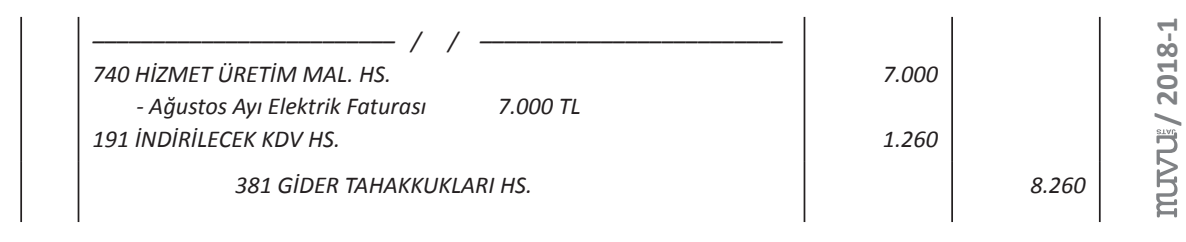

Fatura ödendiğinde yapılması gereken muhasebe kaydı aşağıdaki gibidir.

381 GIDER TAHAKKUKLARI HS.

102 BANKALAR HS.

İşletmenin teşvik almaya hak kazandığı bildirildiğinde yapılması gereken muhasebe kaydı aşağıdaki gibidir. (7.000 TL x 0,20 =1.400 TL)
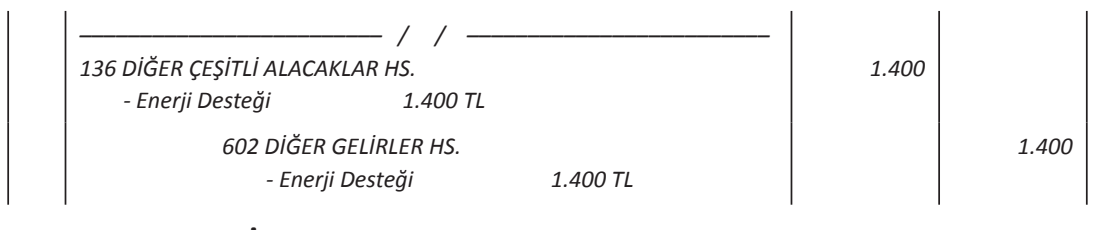

\section{b) Sigorta Primi İşveren Payı Teşviki}

Ücret tahakkuk kaydı aşağıdaki gibi olacaktır.

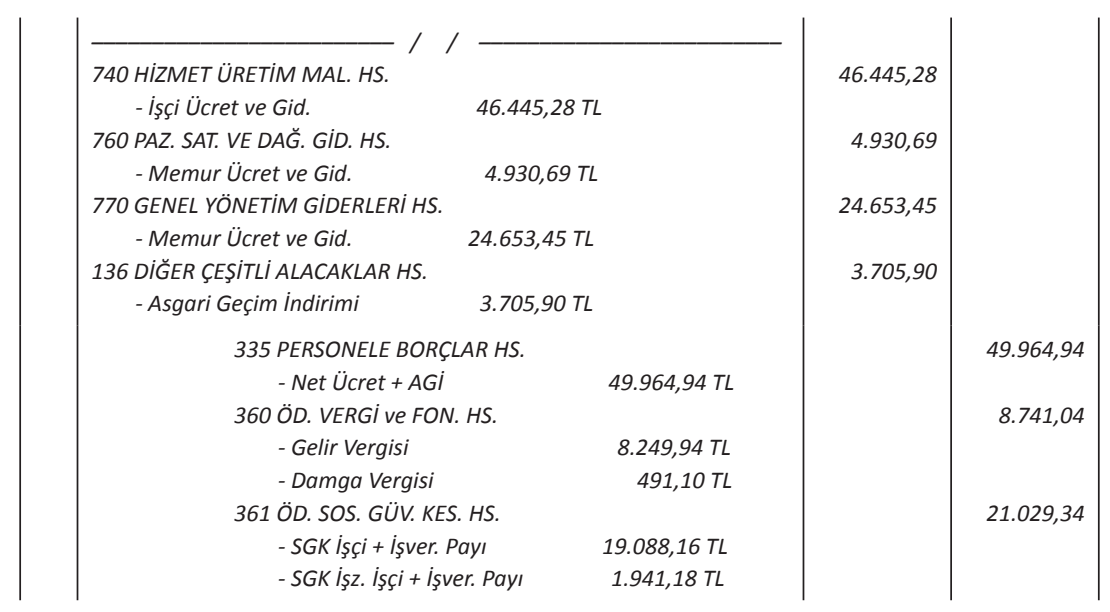

Işletme teşvikten yararlandığında yapılacak kayıt aşağıdaki gibidir.

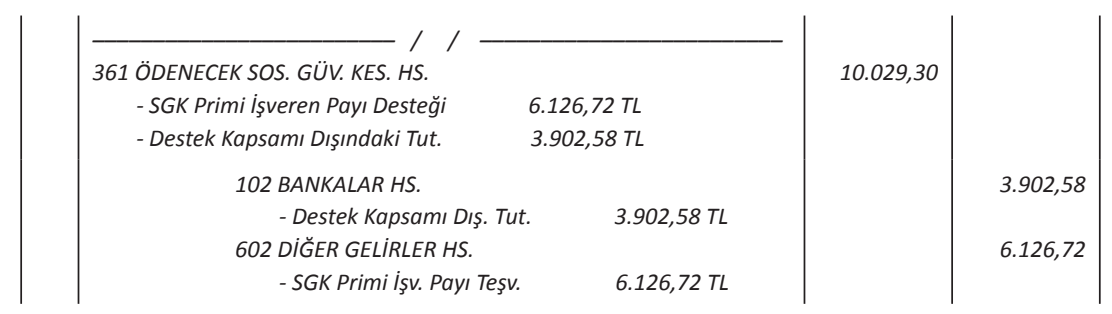


Asgari ücretle çalışan toplam 24 iş̧̧inin her biri için sağlanan 100 TL sigorta primi işveren payı indiriminin muhasebe kaydı aşă̆ıdaki gibidir.

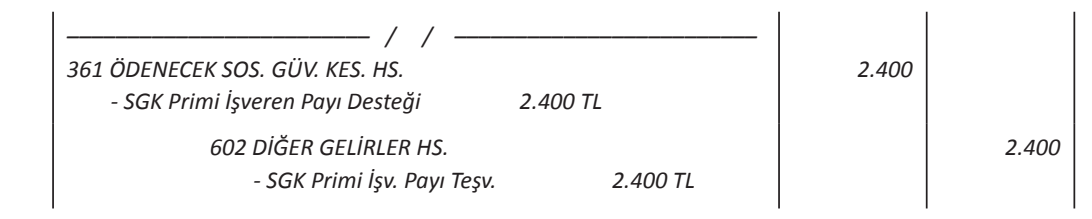

\section{c) Yurtdışı Tanıtım Desteği}

Verilen reklam ile ilgili olarak yapılmış olan harcamalar aşağıdaki gibi muhasebeleştirilmelidir. (4.000 \$ x 3,03 TL=12.120 TL)

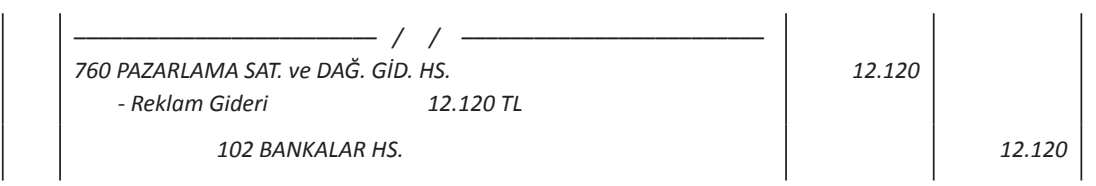

Teşvik kapsamında geri alınacak tutarın tahakkukuna ilişkin muhasebe kaydı aşağıdaki gibi olacaktır. $(2.000 \$$ × 3,03 TL $=6.060 \mathrm{TL})$

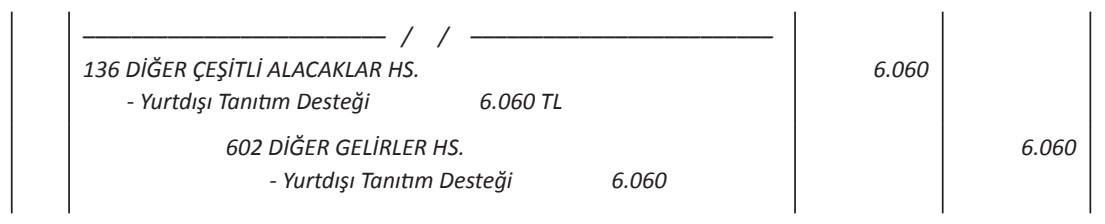

Tekdüzen Muhasebe Sistemi'nde görüldüğü gibi teşviklerin tamamına yakını gelir tablosunun brüt satış karı bölümünde muhasebeleştirilmektedir. Oysa yurtdışı tanıtım desteği gibi teşvikler pazarlama, satış ve dağıtım giderlerini azaltıcı etki yapmaktadır. Bu uygulama ile işletmenin brüt satiş karı yüksek hesaplanmaktadır. Bu durum işletmenin ana faaliyet sonucunu olumlu etkilemektedir. Ancak Tekdüzen Muhasebe Sistemi'ne göre hazırlanan gelir tablosu verilerini kullanmak işletme yöneticilerinin, ortaklarının veya diğer karar alıcıların hatalı kararlar vermelerine neden olabilmektedir.

\subsection{Sonuçların Karşılaştırılması}

Sermaye yaklaşımı, Gelir yaklaşımı ve Tekdüzen Muhasebe Sistemi'ne göre yapılan muhasebeleştirme işlemleri sonucunda elde edilen A Turizm A.Ş.'nin gelir tabloları karşılaştırmalı olarak aşağıda sunulmuştur. 


\begin{tabular}{|c|c|c|c|}
\hline & $\begin{array}{c}\text { SERMAYE } \\
\text { YAKLAȘIMI }\end{array}$ & |GELIIR YAKLAȘIMI & $\begin{array}{l}\text { TEKDÜZEN MUHASEBE } \\
\text { SISTEMİ }\end{array}$ \\
\hline A-BRÜT SATIŞLAR & $1.570 .000,00$ & $1.578 .701,38$ & $1.585 .986,72$ \\
\hline 1-Yurt İçi Satışlar & $1.150 .000,00$ & $1.150 .000,00$ & $1.150 .000,00$ \\
\hline 2-Yurt Dışı Satışlar & $420.000,00$ & $420.000,00$ & $420.000,00$ \\
\hline 3-Diğer Gelirler & & $8.701,38$ & $15.986,72$ \\
\hline \multicolumn{4}{|l|}{ B-SATIŞ İNDİRIMLERI (-) } \\
\hline \multicolumn{4}{|l|}{ 1-Satıştan İadeler ( - ) } \\
\hline \multicolumn{4}{|l|}{ 2-Satıştan İskontalar ( - ) } \\
\hline \multicolumn{4}{|l|}{ 3-Diğer İndirimler ( - ) } \\
\hline C-NET SATIŞLAR & $1.570 .000,00$ & $1.578 .701,38$ & $1.585 .986,72$ \\
\hline D-SATIŞLARIN MALIYYETİ (-) & $520.000,00$ & $520.000,00$ & $520.000,00$ \\
\hline \multicolumn{4}{|l|}{ 1-Satılan Mamüller Maliyeti ( - ) } \\
\hline \multicolumn{4}{|l|}{ 2-Satılan Ticari Mallar Maliyeti ( - ) } \\
\hline 3-Satılan Hizmet Maliyeti (-) & $520.000,00$ & $520.000,00$ & $520.000,00$ \\
\hline \multicolumn{4}{|l|}{ 4-Diğer Satışların Maliyeti ( - ) } \\
\hline BRÜT SATIŞ KARI VEYA ZARARI & $1.050 .000,00$ & $1.058 .701,38$ & $1.065 .986,72$ \\
\hline \multicolumn{4}{|l|}{ E-FAALIYET GIDERLERI } \\
\hline \multicolumn{4}{|l|}{ 1-Araştırma ve Geliştirme Giderleri ( - ) } \\
\hline 2-Pazarlama, Satış ve Dağıtım Giderleri (-) & $180.000,00$ & $180.000,00$ & $180.000,00$ \\
\hline 3-Genel Yönetim Giderleri ( - ) & $290.000,00$ & $290.000,00$ & $290.000,00$ \\
\hline FAALIYET KARI VEYA ZARARI & $580.000,00$ & $588.701,38$ & $595.986,72$ \\
\hline F-DIĞER FAALIYYTLLERDEN OLAĞAN GELİR VE KARLAR & $47.000,00$ & $54.285,34$ & $47.000,00$ \\
\hline \multicolumn{4}{|l|}{ 1-İștiraklerden Temettü Gelirleri } \\
\hline \multicolumn{4}{|l|}{ 2-Bağlı Ortaklıklardan Temettü Gelirleri } \\
\hline 3-Faiz Gelirleri & $20.000,00$ & $20.000,00$ & $20.000,00$ \\
\hline \multicolumn{4}{|l|}{ 4-Komisyon Gelirleri } \\
\hline \multicolumn{4}{|l|}{ 5-Konusu Kalmayan Karşlıklar } \\
\hline \multicolumn{4}{|l|}{ 6-Menkul Kıymet Satış Karları } \\
\hline 7-Kambiyo Karları & $27.000,00$ & $27.000,00$ & $27.000,00$ \\
\hline \multicolumn{4}{|l|}{ 8-Reeskont Faiz Gelirleri } \\
\hline 9-Diğer Olağan Gelir ve Karlar & & $7.285,34$ & \\
\hline \multicolumn{4}{|l|}{ G-DIĞER FAAL. OLAĞAN GİDER VE ZARARLAR(-) } \\
\hline \multicolumn{4}{|l|}{ 1-Komisyon Giderleri (-) } \\
\hline \multicolumn{4}{|l|}{ 2-Karşlık Giderleri (-) } \\
\hline \multicolumn{4}{|l|}{ 3-Menkul Kıymet Satış Zararları ( - ) } \\
\hline 4-Kambiyo Zararları ( - ) & $12.000,00$ & $12.000,00$ & $12.000,00$ \\
\hline \multicolumn{4}{|l|}{ 5-Reeskont Faiz Giderleri (-) } \\
\hline \multicolumn{4}{|l|}{ 6-Diğer Olağan Gider ve Zararlar ( - ) } \\
\hline H-FINANSMAN GIDERLERİ ( - ) & $30.000,00$ & $30.000,00$ & $30.000,00$ \\
\hline 1-Kısa Vadeli Borçlanma Giderleri ( - ) & $30.000,00$ & $30.000,00$ & $30.000,00$ \\
\hline 2-Uzun Vadeli Borçlanma Giderleri ( - ) & & & \\
\hline OLAĞAN KAR VEYA ZARAR & $585.000,00$ & $600.986,72$ & $600.986,72$ \\
\hline I-OLAĞAN DIŞI GELİR VE KARLAR & & & \\
\hline 1-Önceki Dönem Gelir ve Karları & & & \\
\hline 2-Diğer Olağandışı Gelir ve Karlar & & & \\
\hline J-OLAĞANDIŞI GİDER VE ZARARLAR ( - ) & & & \\
\hline 1-Çalışmayan Kısım Gider ve Zararları ( - ) & & & \\
\hline 2-Önceki Dönem Gider ve Zararları ( - ) & & & \\
\hline 3-Diğer Olağandışı Gider ve Zararlar ( - ) & & & \\
\hline DÖNEM KARI VEYA ZARARI & $585.000,00$ & $600.986,72$ & $600.986,72$ \\
\hline K-DÖNEM KARI VERGİ VE DİĞER YASAL YÜK. KARŞ.(-) & $116.500,00$ & $116.500,00$ & $116.500,00$ \\
\hline DÖNEM NET KARI VEYA ZARARI & $468.500,00$ & $484.486,72$ & $484.486,72$ \\
\hline
\end{tabular}

Yukarıda karşılaştırmalı olarak verilen gelir tablosunda turizm teşviklerinin TMS 20'de belirtilen sermaye yaklaşımına, gelir yaklaşımına ve TDMS'ye göre yapılan muhasebeleştirme işlemlerinin raporlama sonuçları yer almaktadır. Bu sonuçları aşağıdaki gibi değerlendirmek mümkündür.

Sermaye yaklaşımına göre bir raporlama yapıldığında gelir tablosunda da görüldüğü üzere teşvik gelirleri hiçbir şekilde gelir tablosuna dahil edilmemekte, teşvik gelirlerinin tamamı bilançonun öz kaynaklar bölümünde raporlanmaktadır.

Gelir yaklaşımına göre yapılan raporlama da ise elde edilen teşvik gelirlerinin bir kısmı gelir tablosunun brüt satış karı bölümünde, bir kısmı olağan 
kar bölümünde raporlanmakta, geriye kalan kısım ise sonraki dönemlerde gelir tablosuna aktarılmak üzere bilançoda ertelenmiş gelir olarak rapor edilmektedir.

TMS-20 standardı kapsamında muhasebeleştirme yapan bir işletme ilgili kayıtlarını sermaye yaklaşımına göre mi yoksa gelir yaklaşımına mı göre muhasebeleştireceğini seçme hakkına sahiptir. Bu da aynı sektörde yer alan işletmelerin birbirinden farklı şekilde muhasebe kaydı tutabileceği anlamına gelmektedir. Bu durum, işletmenin içinde bulunduğu sektör ortalamaları açısından da farkılık yaratacağı için sağlıklı bir karşılaştırma yapılmasına engel olacaktır. Çünkü sermaye yaklaşımına göre kayıt yapılması durumunda elde edilen teşvik gelirleri gelir tablosuna aktarılmayacağından karlılık oranı düşük çıkarken, gelir yaklaşımına göre yapılacak kayıtlarda elde edilen gelirler sistematik bir biçimde gelir tablosuna aktarılacağından kar oranı daha yüksek çıkacaktır. Sabit bir uygulamanın olmaması sektör ortalamasında dalgalanmalara neden olacaktır. Sektördeki konumunu öğrenmek, uyguladıkları işletme politikalarını buna göre değerlendirmek ve yön vermek isteyen karar alıcılar açısından ortaya çıkan oranlar yanıltıcı olabileceğinden hatalı kararlar alınmasına yol açabilecektir.

TMS-20 kapsamında varılacak bir diğer sonuç; sermaye yaklaşımına göre kayıt yapan bir işletmede dönem karı gelir yaklaşımına göre daha düşük çıkacaktır ve bu durum işletmenin daha az kar payı ödemesini sağlayacaktrr. Sermaye yaklaşımında her ne kadar dönem karı düşük hesaplansa da bilançoda özkaynaklar toplamı yüksek olacaktır. Ancak bu durum sermaye ve gelir yaklaşımları açısından işletmenin finansman oranında (özkaynak/ yabancı kaynaklar) önemli bir farklılık doğurmayacaktır.

Diğer yandan sermaye yaklaşımında dönem karının düşük çıkması yatırımcılar ve kredi kuruluşları açısından olumsuz olarak değerlendirilebilecek ve işletmenin yatırım yapmaya uygun olmadığı yönünde karar alınmasına neden olabilecektir.

Tekdüzen Muhasebe Sistemi'ne (TDMS) göre yapılan raporlamada ise teşvik gelirlerinin tamamına yakını diğer gelirler hesabına alınmak suretiyle gelir tablosunun brüt satış karı bölümünde raporlanmaktadır. Bu raporlama yöntemi brüt satış karlılığı üzerinde direkt etki yaparak brüt satış karının yüksek çıkması sonucunu doğurmaktadır.

TDMS'ye göre hazırlanan raporlar işletme yönetimi ve yatırımcılar açısından bir takım olumsuzlukları beraberinde getirmektedir. Bu olumsuzlukları yatırımcılar ve yöneticiler açısından ayrı ayrı değerlendirmek yerinde olacaktır (Çırpan, 2010: 113).

Yatırımcılar açısından ele alacak olursak; TDMS'ye göre yapılacak raporlamada brüt satış karı oranı yüksek çıkacağı için yatırımcılar işletmeyi ana fa- 
aliyet konusu açısından karlı bir işletme gibi görüp yatırım yapmaya uygun görebilirler. Ortaya çıkan bu durum yatırımcıların hatalı yatırım kararları almalarına neden olabilir.

Ortaya çıkabilecek olumsuzlukları yöneticiler açısından ele alacak olursak; işletmenin ana faaliyet konusu açısından karlı bir işletme gibi görünmesi işletmede uygulanan politikaların doğru olduğu sonucunu ortaya çıkaracaktır. Böyle bir durumda yöneticiler işletmenin mevcut yapısında değişiklik yapma ihtiyacı duymayacaktır. Ancak burada göz ardı edilmemesi gereken nokta teşvik gelirlerinin elde edilmediği ya da daha az tutarda elde edildiği varsayıldığında ulaşılacak karlılık oranının işletmenin hedeflediği orana ulaşıp ulaşmadığıdır. Eğer teşvik gelirleri olmadan ortaya çıkan karlılık oranı hedeflenenden düşük ise işletme yönetimi uyguladığı satı̧, pazarlama ya da yönetim politikalarında değişiklik yapma yoluna gidecektir. Ancak TDMS'ye göre yapılan muhasebeleştirme sonucunda ortaya çıkan yüksek karlılık oranlarının işletmede her şeyin yolunda gittiği sonucunu doğurması, işletme ile ilgili hatalı yorumlamalar yapılmasına ve hatalı kararlar alınmasına yol açacaktır.

TDMS'ye göre yapılacak bir raporlamada yöneticilerin hatalı kararlar almasına neden olabilecek diğer bir durum ise teşvik gelirlerinde yaşanabilecek dönemsel dalgalanmalardır. İşletmeler her dönem aynı teşvik türlerinden aynı tutarlarda yararlanamayabilirler. Bu durum teşviklerin kendi yapısından kaynaklanabileceği gibi bürokratik işlemlerden ya da o dönemki ekonomi politikalarından da kaynaklanabilir. Yani işletme bir dönem çok yüksek tutarda teşvik geliri elde ederken bir dönem çok az tutarda elde edebilir veya hiç teşvik geliri elde edemeyebilir. Bu nedenle ortaya çıkacak finansal tablolar ve raporlarla ilgili yapılacak bir karşılaştırma doğru sonuç vermeyeceğinden yöneticilerin alacağı kararların hatalı olması söz konusu olacaktir.

\section{SONUÇ}

Turizm işletmelerine sağlanan devlet teşvikleri 1980 yılından günümüze kadar devam etmekte ve birçok teşvik türü etkin bir şekilde uygulanmaktadır. Sektöre yönelik bu teşvikler hem süreklilik arz etmekte hem de tutar olarak önemli olabilmektedir. Bu kapsamda teşvikler, yatırıma yönelik maliyetlerinin düşürülmesinde, gerekli finansmanın sağlanmasında ve yatırımların ihtiyaç duyulan bölgelerde toplanmasında oldukça etkili araçlardır. Bu araçların kullanılmasındaki amaçlar ekonomik politikalar dahilinde ülkelere göre farklılık göstermekle birlikte, temelde bölgesel farklılıkların ortadan kaldırımasını, uluslararası piyasalarda rekabet gücünün artırılmasını ve yabancı yatırımcıların ülke ekonomisine çekilmesini amaçlamakta- 
dır. Bu amaçlar doğrultusunda sağlanan teşvikler nakdi veya nakdi olmayan unsurlardan oluşabilmektedir. Ancak ülkemizde işletmelerin yararlandığı teşviklerin muhasebeleştirilmesi konusunda halen uygulanmakta olan Tekdüzen Muhasebe Sistemi ile Türkiye Muhasebe Standartları açısından farklılıklar olduğu görülmektedir.

Tekdüzen Muhasebe Sisteminde yer alan uygulama, devlet teşviklerinin gelir tablosunun brüt satış karı bölümünde muhasebeleştirilmesi yönündedir. Oysa teşvik gelirleri sadece işletmelerin satş faaliyeti sonucunda elde etmiş olduğu bir satış hasılatı değildir. Bu şekilde yapılacak bir raporlama işletmenin brüt satı̧ karlılığının olduğundan fazla görünmesine neden olmaktadır. Öyle ki eğer işletme bir hesap dönemi içerisinde yüksek tutarda devlet teşviki almışsa bu uygulamaya göre brüt satış karlılığı ciddi boyutlarda artacak ve bu durum gerek işletme sahipleri gerekse finansal tablo kullanıcıları açısından hatalı kararlar verilmesine neden olabilecektir. Bu nedenle teşvik gelirlerinin yalnızca gelir tablosunun brüt satış karı bölümü yerine; işletmenin ana faaliyet konusu ile ilgili olup olmamasına ve süreklilik arz edip etmemesine göre olağan kar veya dönem karı bölümünde raporlanması, raporlama açısından daha doğru bir uygulama olacaktır.

Diğer taraftan TDMS kapsamında yapılan muhasebeleştirme işlemleri yalnızca raporlama açısından değil aynı zamanda vergisel açıdan da bir takım olumsuzlukları beraberinde getirmektedir (Çırpan, 2010: 114). Elde edilen teşvik gelirlerinin direkt olarak gelir tablosuna aktarılması sonucunda karlılığın yüksek çıkması, işletmenin ödemesi gereken vergi yükünü artırıcı bir unsur oluşturmaktadır. Çünkü vergilendirmeye yönelik mevcut düzenlemelerde hatalı bir uygulama söz konusudur. Şöyle ki Gelir Vergisi Kanunu ve Kurumlar Vergisi Kanunu'na göre teşvikler, ticari kazancın elde edilmesi veya idame ettirilmesi amacıyla yapılan faaliyetler sonucunda elde edilmiş gelirlerdir ve dönem karına dahil edilerek vergilendirilmesi gerekmektedir (Çırpan, 2010: 115). Bu düzenleme nedeniyle yatırımların maliyetlerini azaltmaya yönelik olarak verilen teşvikler bir anlamda maliyetin kendisini oluşturmaktadır. Devlet tarafindan verilen teşvikler bir yandan da vergilendirme yoluyla işletmeden geri alınmaktadır. Ancak bu durum teşviklerin yapısına ve amacına tamamıla aykırı bir durumdur. Bu hatalı uygulama işletmelerin teşviklerden tam anlamıyla faydalanabilmesini engellemekte ve teşviklerin etkinliğini azaltmaktadır. Bu durumun ortadan kaldırılabilmesi için gerekli yapısal değişikliklerin yetkili kurum ve kuruluşlar tarafindan yapılması gerekmektedir (Çırpan, 2010: 115).

Sermaye yaklaşımında teşvik gelirlerinin tamamının öz kaynaklar grubu altında raporlanması işletmelerin sermaye yapılarının güçlenmesine katkı sağlamaktadır. Ancak elde edilen teşvik gelirleri gelir tablosuna aktarılamadığından işletmenin dönem karı düşük hesaplanmaktadır. Bu durum ise 
işletmeler açısından avantaj sağlayııı bir unsura dönüşmektedir. Çünkü bu yaklaşım kapsamında gelir tablosuna aktarılamayan teşvik gelirleri nedeniyle işletme ortaklarına daha az temettü ödeyecektir. Böylece teşviklerden sağlanan fayda artmaktadır.

Gelir yaklaşımında teşvik gelirleri elde edildiği anda ertelenmiş gelir olarak bilanço hesaplarında takip edilmekte ve teşvikle ilgili giderler ortaya çıktıça sistematik bir şekilde bilançodan gelir tablosuna aktarılarak gelir ve giderin birbirini netleştirmesi sağlanmaktadır. Böylece bilanço hesaplarında ertelenmiş gelir olarak bekletilen gelirler için herhangi bir vergilendirme söz konusu olmadığı gibi aynı zamanda bu uygulama dönemsellik ilkesi açısından da önem arz etmektedir.

TMS-20 Standardı ve TDMS kapsamında devlet teşviklerin muhasebeleştirilmesi konusunda ortaya çıkan raporlamaya ve vergilendirmeye yönelik olumsuzlukların ortadan kaldırması ile ilgili çeşitli adımlar atmak mümkündür (Çırpan, 2010: 115-116).

Öncelikli olarak devlet teşvikleri ile ilgili Tekdüzen Muhasebe Sistemi'nin TMS-20 standardı ile uyumlu hale getirilmesi gerekmektedir. Bu konuda atıması gereken ilk adım, uygulanmakta olan hesap planının yeniden gözden geçirilmesidir. Yapılacak uyumlaştırma çalışmaları ile hem raporlamaya yönelik riskler ortadan kaldırılabilir hem de vergilendirmeye yönelik hatalı uygulamalara son verilebilir. Tekdüzen hesap planında sadece ana hesap grupları tanımlanarak, boş bırakılacak alt hesaplarla işletmelerin sektör bazında intiyaca göre bu hesapları düzenleyebilmesine izin verilmelidir. Böylece işletmelerin kendileri için gereksiz olan hesapların gelir tabIolarında yer almaması sağlanabilir. Uyumlaştırma çalışmaları ile TDMS'de yapılacak değişiklikler teşviklerin veriliş amaçlarını gerçekleştirmesinde oldukça etkili olacaktr.

Olumsuzlukların ortadan kaldırılmasına yönelik olarak atılabilecek bir diğer adım ise; kurumlar vergisi beyannamesi üzerinde yapılacak yapısal bir değişiklik ile teşvik gelirlerinin vergilendirme dışı bırakılmasıdır. Yapılacak değişiklik; kurumlar vergisinden istisna edilmiş kazançların vergilendirme dışı bırakılması için beyanname üzerine açılmış indirim ve istisnalar bölümünün alttna teşvik gelirlerinin de dahil edilmesidir. Böylece beyanname üzerinde yer alacak bölüme teşvikin türü ve tutarı gibi gerekli bilgilerin yazılması suretiyle teşvik geliri vergi matrahından indirilerek vergilendirme dışı bırakılabilecektir.

Son olarak ise ülkemizde teşviklerle ilgili düzenlemelerin farklı mevzuat türleri ile yapılması, bazı teşviklerin süreyle sınırlandırılması ve düzenleme yapan kurumların farklıık göstermesi uygulamada karışıkıkların yaşanmasına neden olmaktadır. İşletme birden fazla teşvik türünden yararlanmak istedi- 
ğinde ilgili teşviklerin farklı mevzuat türünde ve farklı kurumlar tarafindan düzenlenmiş olması işletmeler açısından bürokratik süreci uzatmakta ve zaman kaybına neden olmaktadır. Ayrıca uygulama aşamasında yaşanan karmaşıkıklar teşviklerin etkinliğini ve verimliliğini azaltmaktadır. Bu nedenle devlet teşviklerinin aynı mevzuat içine alınması ve düzenleyici kurumların tek bir çatı altında toplanması teşviklerden sağlanacak faydayı artıracaktır.

\section{KAYNAKÇA}

Akay, H. (2009). Türk Turizm Sektöründe Teşvikler ve TMS 20 Çerçevesinde Muhasebeleştirilmesi. İstanbul: Türkmen Kitabevi.

Akay, H. ve Oğuz, M. (2015). Türk Turizm Sektöründe Teşvikler ve 20 No'lu Türkiye Muhasebe Standardı Çerçevesinde Muhasebeleştirilmesi. Niğde Üniversitesi iktisadi ve Idari Bilimler Fakültesi Dergisi, 8(4), 213-228.

Akdoğan, N. ve Sevilengül, O. (2003). Türkiye Muhasebe Standartları ile Uyumlu Tekdüzen Muhasebe Sistemi Uygulaması. Ankara: Gazi Kitabevi.

Aydoğuş, I., Soybalı, H. H. ve Baytok, A. (2006). Yunanistan ile Türkiye'de Uygulanan Turizm Yatııı Teşviklerinin Karşılaştırılması. Afyon Kocatepe Üniversitesi IiBF Dergisi, 8(1), 1-20.

Çırpan, E. (2010). Devlet Teşviklerinin Muhasebeleştirilmesinin Türkiye Muhasebe Standartları ve Muhasebe Sistemi Uygulama Genel Tebliğleri Açısından Karşılaştırılması, Yüksek Lisans Tezi, İstanbul Üniversitesi Sosyal Bilimler Enstitüsü.

Çiloğlu, ì. (1997). Teşvik Sisteminin Değerlendirilmesi. Hazine Dergisi. 8, 1- 15.

Gençoğlu, Ü. G., Özerhan, Y. ve Karabınar, S. (2013). Türkiye Finansal Raporlama Standartları. Sakarya: Sakarya Üniversitesi Sürekli Eğitim Uygulama ve Araştırma Merkezi Yayınları.

Kayalı, N. ve Terim, B. (2012). TMS 20 Standardına Göre Devlet Teşviklerinin ve Devlet Yardımlarından Sağlanan Desteklerin Muhasebe Açısından Incelenmesi. Dayanışma Dergisi, 115, 34-43.

Küçükkahraman, B. (2013). TMS 20 Standardına Göre Devlet Teşviklerinin Muhasebeleştirilmesi: Örnek Uygulamalar. Yüksek Lisans Tezi, Afyon Kocatepe Üniversitesi Sosyal Bilimler Enstitüsü.

Mackenzie, B., Coetsee, D., Njikizana, T., Chamboko, R., Colyvas, B., ve Hanekom, B. (2012). Wiley IFRS 2013: Interpretation and Application of International Financial Reporting Standards. Hoboken, New Jersey: John Wiley \& Sons. 
Okutmuş, E., Uyar, S. ve Gövce, M. (2015). Sağlık Turizminde Devlet Teşviklerinin TMS 20 Kapsamında Muhasebeleştirilmesi. C.Ü. Iktisadi ve Idari Bilimler Dergisi, 16(2), 63-82.

Öner, E. (2002). Niçin Vergi Teşvikleri?. Atatürk Üniversitesi iiBF Dergisi, 3-4(16), 97-119.

Toker, B. (2007). Türkiye'de Turizm Sektörü Teşviklerinin Değerlendirilmesi. Celal Bayar Üniversitesi IiBF Dergisi, 14(2), 82-92.

Ulusan, H. (2008). Türk Muhasebe Hukuku Çerçevesinde Devlet Teşviklerinin Muhasebeleştirilmesi ve Raporlanması. Atatürk Üniversitesi iiBF Dergisi, 22(2), 415-433.

Türkiye Muhasebe Standartları 20 Nolu Tebliğ, Devlet Teşviklerinin Muhasebeleştirilmesi ve Devlet Yardımlarının Açıklanması (TMS 20) Hakkında Tebliğ, Sıra No: 8., Erişim tarihi: 03.07.2017. http://www.resmigazete.gov. tr/eskiler/2005/11/20051101-6.htm

Yavuz, A. (2010). Bir Maliye Politikası Aracı Olarak Yatırım Teşviklerinin Rekabet Koşulları Altında Özel Kesim Yatırımları ve İstihdam Üzerine Etkisi: Ekonometrik Bir Analiz. Süleyman Demirel Üniversitesi IiBF Dergisi, 15(1), 83-101. 